\title{
PENGARUH SOLVABILITAS, SEGMEN OPERASI, DAN REPUTASI KAP TERHADAP AUDIT DELAY PADA PERUSAHAAN MANUFAKTUR DI INDONESIA
}

\author{
Herni Kurniawati, Fanny Andriani Setiawan dan Septian Bayu Kristanto \\ Fakultas Ekonomi Universitas Tarumanagara \\ Email:hernik@fe.untar.ac.id
}

\begin{abstract}
Abstact: Timeliness is one of the indicators used in the measure how quickly and accurately a company in publish financial reports in the context of decision making for investors. The information presented on time is considered able to provide a description of the condition that the company in a state of healthy both in the financial management internal control and routine operational activities. Audit delay is defined as a shift in the time that caused by delays in the settlement of the annual financial audit reports. This can occur because of a problem that appears not only from internal company but can also occur because of external factors. In this research we examined whether the solvency, operating segment of the company, and reputation Public Accountant (the big four and non-the big four) have an impact on the duration and scope of the work of the auditor. The object of this research is manufacturing companies listed in Indonesia Stock Exchange period 2011-2013. This research uses linear regression to test is whether or not the influence of solvency, operating segment and reputation Public Accountant to audit delay, aided by a software program eviews 6 and PASW Statistics 18. The results of this research are (1) the level of solvency of companies has positive effect on audit delay, (2) the number of business segments and the number of geographical segment has a negative effect on audit delay, (3) the reputation of Public Accountant has positive effect on audit delay.
\end{abstract}

Keywords: Level of solvency, operating segment, reputation public accountant, and audit delay

\begin{abstract}
Abstrak: Ketepatan waktu (Timeliness) adalah salah satu indikator yang digunakan dalam mengukur seberapa cepat dan tepat sebuah perusahaan dalam mempublikasikan laporan keuangan dalam rangka pengambilan keputusan bagi para investor. Informasi yang disajikan tepat waktu dianggap dapat memberikan suatu gambaran bahwa kondisi perusahaan tersebut dalam keadaan yang cukup sehat baik dalam pengelolaan keuangan, pengendalian internal, dan rutinitas kegiatan operasional. Audit delay didefinisikan sebagai pergeseran waktu yang disebabkan oleh keterlambatan penyelesaian laporan audit keuangan tahunan. Hal ini dapat terjadi karena adanya masalah yang muncul tidak hanya dari internal perusahaan tetapi bisa juga terjadi karena faktor eksternal. Pada penelitian ini kami menguji apakah solvabilitas, segmen operasi perusahaan, dan reputasi Kantor Akuntan Publik (the big four dan non-the big four) berdampak kepada durasi dan ruang lingkup pekerjaan auditor. Objek penelitian ini adalah perusahaan manufaktur yang terdaftar di Bursa Efek Indonesia periode tahun 2011-2013. Penelitian ini menggunakan regresi linear untuk menguji ada tidaknya pengaruh solvabilitas, segmen operasi, dan reputasi KAP terhadap audit delay, yang dibantu dengan program software eviews 6 dan PASW Statistic 18. Hasil penelitian
\end{abstract}


adalah (1) tingkat solvabilitas perusahaan berpengaruh positif terhadap audit delay, (2) jumlah segmen usaha dan jumlah segmen geografis tidak berpengaruh positif terhadap audit delay, (3) Reputasi Kantor Akuntan Publik berpengaruh positif terhadap audit delay.

Kata kunci : Solvabilitas, segmen operasi, reputasi KAP, audit delay

\section{PENDAHULUAN}

Di dalam dunia perekonomian, laporan keuangan merupakan bagian yang tidak terpisahkan dalam suatu perusahaan baik berupa Firma, Perusahaan Perseorangan maupun Perusahaan Terbuka. Laporan keuangan harus mencakup informasi keseluruhan aset, kewajiban, dan ekuitas yang dimiliki dan dikuasai oleh sebuah entitas dalam menjalankan kegiatan operasional. Tujuan dari penyajian laporan ini adalah untuk memberikan gambaran kepada para pelaku ekonomi termasuk di dalamnya investor dan para stakeholder untuk dapat menganalisa kondisi keuangan entitas dalam kaitannya dengan kelangsungan hidup perusahaan tersebut. Dari informasi tersebut, para investor maupun stake-holders bisa mengambil sebuah keputusan yang bersifat ekonomis terkait investasi yang dilakukan.

Dalam penyajian laporan keuangan, salah satu karakteristik kualitatif yang harus dipenuhi adalah relevan. Dianggap relevan, jika sebuah informasi itu mempunyai kemampuan untuk mempengaruhi dalam hal pengambilan keputusan dan diberikan tepat waktu guna mempengaruhi pengambilan keputusan (Kerangka Dasar Penyusunan Dan Penyajian Laporan Keuangan. SAK, 2012). Informasi yang disajikan tepat waktu dianggap dapat memberikan suatu gambaran bahwa kondisi perusahaan tersebut dalam keadaan yang cukup sehat baik dalam pengelolaan keuangan, pengendalian internal dan rutinitas kegiatan operasionalnya. Seperti yang dipaparkan Rachmawati (2008), Nilai dari ketepatan waktu pelaporan keuangan merupakan faktor penting bagi pemanfaatan laporan keuangan. Dampak yang dihasilkan dari ketepatan waktu (timeliness) penyajian laporan keuangan akan memberikan andil bagi kinerja yang efisien di pasar saham yaitu sebagai fungsi evaluasi dan pricing, mengurangi tingkat insider trading dan kebocoran serta rumor - rumor di pasar saham.

Dikarenakan laporan keuangan ini tidak hanya berdaya guna bagi perusahaan, tetapi juga diperlukan bagi pihak lain seperti investor, kreditur, pemerintah maupun masyarakat luas, maka BAPEPAM selaku badan pengawas pasar modal dan lembaga keuangan mengeluarkan peraturan yang diatur dalam UU no. 8 Tahun 1995 tentang Pasar Modal dan Keputusan Ketua Bapepam No. 80/PM/1996 tentang kewajiban penyampaian laporan keuangan berkala, dan pada 30 September 2003 dikeluarkan peraturan No.X.K.2, perihal keputusan Ketua Badan Pengawas Pasar Modal No.KEP-36/PM/2003 tentang kewajiban penyampaian laporan keuangan berkala, yang menyatakan laporan keuangan tahunan disertai dengan laporan akuntan dengan pendapat lazim harus disampaikan kepada Bapepam selambat-lambatnya pada akhir bulan ketiga (90 hari) setelah tanggal laporan keuangan tahunan. Selain itu, juga terdapat Keputusan Direksi PT. Bursa Efek Jakarta No: Kep-307/BEJ/07-2004 tentang Peraturan Nomor I-H tentang sanksi yang dikeluarkan oleh Bursa terhadap pelanggaran peraturan berupa peringatan tertulis, denda maksimal Rp. 500.000.000,- hingga penghentian sementara perdagangan efek perusahaan tercatat di bursa. Keharusan laporan keuangan tahunan disertai laporan akuntan dengan pendapat 
lazim menimbulkan adanya keterlibatan pihak eksternal perusahaaan yaitu Kantor Akuntan Publik. Dengan adanya peran serta pihak eksternal juga memberikan dampak lain yang dapat menjadi penyebab terjadinya keterlambatan publikasi laporan keuangan. Di samping itu, dalam pelaksanaan audit diperlukan pemenuhan standar audit yang tercantum dalam Standar Profesional Akuntan Publik, salah satu butir yang tercantum dalam standar umum yang menyangkut kecermatan dalam melakukan semua aspek auditing. (Febrianty, 2011).

Keterlambatan publikasi laporan keuangan mengindikasikan adanya masalah yang terjadi dalam perusahaan sehingga mengakibatkan semakin lamanya penyelesaian audit yang dilaksanakan dan terjadilah audit delay. Audit delay merupakan suatu kejadian dimana terjadinya pergeseran waktu penyampaian laporan keuangan ke Bapepam yang berdampak kepada kemampuan mempengaruhi investor dalam hal mengambil keputusan ekonomis. Jarak waktu antara akhir periode akuntansi dengan tanggal ditandatanganinya laporan audit dapat mempengaruhi ketepatan waktu informasi tersebut dipublikasikan (Febrianty 2011). Fenomena yang timbul dari audit delay adalah berkurangnya relevansi dari laporan keuangan yang disajikan sehingga menimbulkan keraguan para investor terhadap kredibilitas perusahaan dalam melakukan investasi dan beralih untuk mencari informasi mengenai perusahaan lain (Lee dan Jahng 2008) dan adanya sanksi yang dikenakan akan merugikan pihak perusahaan, namun mengapa audit delay masih terjadi pada beberapa perusahaan go public? Seperti yang terlihat dalam kasus yang disajikan dalam headline tanggal 7 Agustus 2012 yang menyatakan bahwa PT. Davomas Abadi disuspensi oleh BEI karena belum menyampaikan laporan keuangan tahun 2011 dan belum membayar denda (infobanknews.com).

Penelitian ini merupakan replikasi dari penelitian Rachmawati (2012) dan Febrianty (2011). Variabel solvabilitas dan reputasi Kantor Akuntan Publik dibahas kembali dalam penelitian ini, sedangkan kontribusi dalam penelitian ini adalah pengujian variable segmen operasi yang berdampak kepada durasi dan ruang lingkup pekerjaan auditor. Sehingga, penulis tertarik untuk meneliti lebih lanjut tentang Pengaruh Solvabilitas, Segmen Operasi, dan Reputasi KAP terhadap Audit Delay.

Audit Delay. Ketepatan waktu (Timeliness) adalah salah satu indikator yang digunakan dalam mengukur seberapa cepat dan tepat sebuah perusahaan dalam mempublikasikan laporan keuangan dalam rangka pengambilan keputusan bagi para investor. Memiliki informasi yang relevan tersedia lebih cepat dapat meningkatkan kapasitasnya untuk mempengaruhi keputusan, dan kurangnya ketepatan waktu dapat mengurangi manfaat dari informasi tersebut (Kieso,Weygant dan Warfield 2011). Dalam kerangka konseptual yang diterapkan oleh SAK (IAI, 2012) mengungkapkan bahwa jika terdapat penundaan yang tidak semestinya dalam pelaporan, maka informasi yang dihasilkan akan kehilangan relevansinya. Suatu informasi yang disajikan tepat waktu tidak menjamin relevansi tetapi relevansi informasi tidak dimungkinkan tanpa ketepatan waktu (timeliness) informasi mengenai kondisi dan proses perusahaan harus cepat dan tepat sampai kepada pengguna laporan keuangan (Rachmawati, 2008).

Audit delay terdiri dari 3 komponen (Rosmawati dan Supriyanti 2012), yaitu: (1) Scheduling Lag, yaitu selisih waktu antara akhir tahun fiskal perusahaan dengan dimulainya pekerjaan lapangan auditor; (2) Fieldwork Lag, yaitu selisih waktu antara 
dimulainya pekerjaan lapangan dan saat penyelesaiannya; (3) Reporting Lag, yaitu selisih waktu antara saat penyelesaian pekerjaan lapangan dengan tanggal laporan auditor.

Audit delay didefinisikan sebagai pergeseran waktu yang disebabkan oleh keterlambatan penyelesaian laporan audit keuangan tahunan. Hal ini dapat terjadi karena adanya masalah yang muncul tidak hanya dari internal perusahaan tetapi bisa juga terjadi karena faktor eksternal. Perusahaan dengan sistem pengendalian internal yang baik akan memberikan dampak positif terhadap ketepatan waktu dalam penyelesaian laporan keuangan, tetapi tidak menutup kemungkinan terjadinya audit delay.

Solvabilitas. Posisi keuangan entitas dipengaruhi oleh sumber daya yang dikendalikan, struktur keuangan, likuiditas dan solvabilitas serta kemampuan beradaptasi terhadap perubahaan lingkungan. Merujuk kepada SAK, Solvabilitas merupakan ketersediaan kas jangka panjang untuk memenuhi komitmen pada saat jatuh tempo. Solvabilitas adalah rasio yang digunakan untuk mengukur kemampuan perusahaan dalam memenuhi kewajiban baik jangka pendek maupun jangka panjang. Dalam penelitian ini, rasio pengukuran yang akan digunakan adalah Debt to Total Equity yang menggambarkan perbandingan hutang dengan total ekuitas.

Debt to Total Equity dapat digunakan sebagai indikator tingkat kesulitan keuangan perusahaan. Proporsi Debt to Total Equity yang tinggi meningkatkan kegagalan perusahaan sehingga kecurigaan auditor meningkat karena adanya kemungkinan laporan keuangan kurang dapat dipercaya dan memberikan sinyal bahwa perusahaan sedang dalam kesulitan keuangan. Analisa solvabilitas sebagai alat untuk mengukur kemampuan perusahaan dalam menyelesaikan seluruh kewajibannya (Sugiarto, 2012). Solvabilitas juga mengindikasikan jumlah modal yang dikeluarkan oleh investor dalam menghasilkan laba. Beberapa perusahaan dapat segera melaporkan hasil audit laporan keuangan lebih cepat untuk meyakinkan pemegang ekuitas yang dapat mengurangi resiko premium dalam tingkat pengembalian ekuitas. Publikasi laporan keuangan yang lebih cepat dapat terlaksana jika pekerjaan audit telah dicapai. Di sisi lain, ada kemungkinan bahwa perusahaan dengan tingkat rasio hutang terhadap ekuitas yang tinggi akan menyamarkan tingkat resiko dan mengalami keterlambatan dalam mempublikasikan laporan keuangan. (Prince et al., 2012).

Segmen Operasi. Selain laporan keuangan, salah satu sumber informasi penting bagi para pengguna laporan keuangan ialah informasi mengenai segmen perusahaan.Menurut The Association for Investment Management and Research (AIMR) menyatakan segmen reporting merupakan hal penting, "Observing of user demand for segment information; It is vital, essential, fundamental, indispensable and integral to the investment analysis process" (Megalia dan Sylvia, 2012).

Berdasarkan PSAK no.5 (2012), segmen operasi adalah suatu komponen dari entitas: (a) Yang terlibat dalam aktivitas bisnis yang mana memperoleh pendapatan dan menimbulkan beban (termasuk pendapatan dan beban terkait dengan transaksi dengan komponen lain dari entitas yang sama); (b) Hasil operasinya dikaji ulang secara regular oleh pengambil keputusan operasional untuk membuat keputusan tentang sumber daya yang dialokasikan pada segmen tersebut dan menilai kinerjanya; dan (c) Tersedia informasi keuangan yang dipisahkan. Segmen operasi dapat terlibat dalam aktivitas bisnis yang belum menghasilkan pendapatan, misalnya operasi permulaan dapat menjadi segmen operasi sebelum memperoleh pendapatan. 
Segmen operasi seringkali memperlihatkan kinerja keuangan jangka panjang serupa jika mereka memiliki karakteristik ekonomi serupa. Dua atau lebih segmen operasi dapat diagregasikan dalam suatu segmen operasi tunggal jika agregasi tersebut konsisten dengan prinsip utama, segmen tersebut memiliki karakteristik ekonomi serupa, dan segmen tersebut serupa dalam setiap hal berikut ini: (a) Sifat produk dan jasa; (b) Sifat proses produksi; (c) Jenis atau kelompok pelanggan untuk produk dan jasanya; (d) Metode yang digunakan untuk mendistribusikan produk dan penyediaan jasanya; dan (e) Jika diterapkan, sifat lingkungan pengaturan misalnya, perbankan, asuransi dan utilitas publik.

Dikarenakan variasi segmen yang ada, perusahaan mengalami kendala dalam pemisahan dan pengungkapan dampak dari masing masing segmen terjadi. Oleh karena itu, ditetapkanlah aturan pelaporan bagi segmen industri, aktivitas internasional, penjualan ekspor dan pelanggan utama.Pemisahan segmen industri dan geografis dapat memberikan informasi tambahan (incremental information) bagi analis dan investor terkait berbagai pasar berbeda dimana perusahaan beroperasi. (Megalia dan Sylvia, 2012).

Data segmen membantu analisis operasi perusahaan dalam memberikan tingkat profitabilitas, risiko dan pertumbuhan yang beragam. Evaluasi atas segmen bisnis ini juga cukup membantu calon investor dan para stake-holders untuk membuat penilaian yang lebih baik atas kinerja perusahaan dalam menghasilkan laba bagi perusahaan. Dalam pelaporan segmen, perusahaan harus mengidentifikasi ragam produk dan jasa yang menghasilkan laba, dan mengelompokkan produk berdasarkan area geografis serta jumlah segmen.Dampak yang timbul akibat pelaporan segmen bisnis adalah penentuan pelaporan segmen, alokasi joint cost dan transfer pricing.

Fitriany dan Aulia (2009) menyatakan bahwa informasi segmen berperan bagi pengguna laporan keuangan untuk melakukan penilaian dan analisis investasi. Salah satu informasi pada segmen perusahaan yang menjadi perhatian utama para pengguna laporan keuangan ialah informasi pertumbuhan laba setiap segmen perusahaan.Informasi pertumbuhan laba, baik pada perusahaan secara keseluruhan dan segmen-segmennya, memiliki incremental value bagi investor dan kompetitor melebihi informasi laba saja (seperti profit rate). Seperti yang dikutip oleh David et.al (2013) bahwa semua stakeholders dalam proses pelaporan keuangan harus menyadari keterlibatan auditor dalam kesalahan pelaporan tingkat segmen. Pelaporan segmen memberikan pengaturan yang menarik untuk memeriksa penilaian resiko auditor karena kebijaksanaan yang diberikan manajemen terhadap peraturan yang berlaku. Jika pelaporan segmen tidak dianggap sebagai masalah audit yang signifikan, apakah auditor akan peka terhadap resiko terkait dengan manipulasi klasifikasi segmen.Pernyataan yang dikutip oleh Megalia dan Bestari menyebutkan bahwa informasi segmen berperan penting dalam melakukan penilaian ekuitas perusahaan. Informasi segmen mampu memberikan incremental value pada perusahaan dengan profitabilitas segmen yang divergen atau disebut dengan Divergence of Profitability (DOP).

Penelitian yang dilakukan oleh Wan-Hussin dan Bamahros (2012) perihal faktor yang mempengaruhi audit delay dimana salah satu variabelnya yaitu kompleksitas bisnis yang diukur menggunakan produk segmen dan geografis segmen, dimana semakin kompleks sebuah perusahaan ikut mempengaruhi penyelesaian audit dan memungkinkan terjadinya keterlambatan dalam publikasi laporan keuangan.

Reputasi KAP. Kewajiban penyampaian laporan keuangan tahunan kepada BAPEPAM dengan disertai laporan akuntan publik mengharuskan adanya campur tangan pihak 
eksternal perusahaan yaitu Kantor Akuntan Publik.Nilai laporan auditor dan permintaan atas jasa audit tergantung pada kepercayaan masyarakat terhadap independensi dan integritas akuntan publik. Oleh karena itu,informasi keuangan harus disajikan dengan akurat oleh Kantor Akuntan Publik.Seperti yang dijabarkan oleh Febrianty 2011 bahwa, Kantor Akuntan Publik internasional atau yang dikenal dengan Big Four dianggap dapat melaksanakan auditnya secara efisien dan memiliki jadwal waktu yang lebih tinggi untuk menyelesaikan audit tepat pada waktunya. Waktu yang cepat adalah cara bagi Kantor Akuntan Publik (KAP) besar untuk mempertahankan reputasinya karena jika tidak menyelesaikan audit dengan cepat maka untuk tahun yang akan datang mereka akan kehilangan kliennya.

Empat kategori ukuran digunakan untuk menggambarkan Kantor Akuntan Publik yaitu Kantor internasional empat besar, kantor nasional, kantor regional, dan kantor lokal yang besar serta kantor lokal yang kecil. Dalam penelitian ini, peneliti menggunakan kantor internasional empat besar di Indonesia yang terdiri dari: (1) KAP Price Waterhouse Coopers (PWC), bekerjasama dengan KAP Drs. Hadi Sutanto \& Rekan, Haryanto Sahari \& Rekan; (2) KAP Klynvelt Peat Marwick Goerdeler (KPMG), bekerjasama dengan KAP Sidharta - Sidharta \& Widjaja; (3) KAP Ernst \& Young (E\&Y), bekerjasama dengan KAP Prasetio, Sarwoko \& Sandjaja; (4) KAP Deloitte Touche Thomatsu (Deloitte), bekerjasama dengan KAP Hans Tuanakota \& Mustofa Osman Ramli Satrio \& Rekan.

\section{KAJIAN TEORI}

Penelitian atas audit delay dengan menggunakan tingkat solvabilitas yang diukur dengan Total Hutang dibagi dengan total ekuitas dilakukan Supriyati dan Rosmawati (2012) didapatkan pengaruh positif atas tingkat solvabilitas terhadap audit delay dan dijelaskan bahwa perusahaan dengan tingkat proporsi hutang yang lebih kecil menunjukkan audit delay yang lebih rendah. Penelitian Febrianty (2011) terhadap audit delay dengan menggunakan variabel solvabilitas yang menggunakan proksi Debt to Total Asset Ratio berpengaruh signifikan terhadap audit delay. Hasil yang sama didapatkan dari penelitian Novice dan Budi (2010) serta Susilawatiet.al.(2012), Ettredge et.al. (2006), rasio solvabilitas menunjukkan signifikansi terhadap audit delay sedangkan oleh Karim dan Ahmed (2006), Shultoni (2012) dan Meylisa \& Estralita (2010) tidak menemukan hubungan yang signifikan. Berdasarkan uraian tersebut, maka hipotesis dirumuskan sebagai berikut:

H1 : Tingkat Solvabilitas berpengaruh positif terhadap audit delay

Hasil penelitian yang dipaparkan dalam Wan-Hussin dan Bamahros (2012) perihal faktor yang mempengaruhi audit delay dimana salah satu variabelnya yaitu kompleksitas bisnis yang diukur menggunakan produk segmen dan geografis segmen, dimana semakin kompleks sebuah perusahaan maka akan ikut mempengaruhi penyelesaian audit. Penelitian Knechel dan Sharma (2008) menerangkan bahwa perusahaan industri yang mempunyai lini bisnis lebih dari satu akan mengalami audit delay yang lebih panjang. Berdasarkan uraian tersebut, maka hipotesis dirumuskan sebagai berikut:

$\mathbf{H}_{2 \mathbf{a}}$ : Jumlah Segmen usaha berpengaruh positif terhadap audit delay

$\mathbf{H}_{2 b}$ : Jumlah segmen geografis berpengaruh positif terhadap audit delay

Penelitian pengaruh reputasi kualitas KAP telah banyak dilakukan dan diantaranya hasil penelitian yang dilakukan oleh Shultoni (2012), Pasca dan Roza (2013) menunjukkan 
bahwa Kantor Akuntan Publik (KAP) berpengaruh terhadap audit delay dan juga didukung oleh penelitian Shukeri dan Islam (2012). Sedangkan, hasil penelitian Febrianty (2011) tidak menunjukkan pengaruh antara KAP terhadap audit delay. Berdasarkan penelitian sebelumnya yang dijabarkan diatas, maka hipotesis yang diuji dalam penelitian ini adalah:

H3 : Reputasi Kantor Akuntan Publik berpengaruh negatif terhadap audit delay

Kerangka Penelitian. Adapun kerangka penelitian dalam penelitian ini adalah :

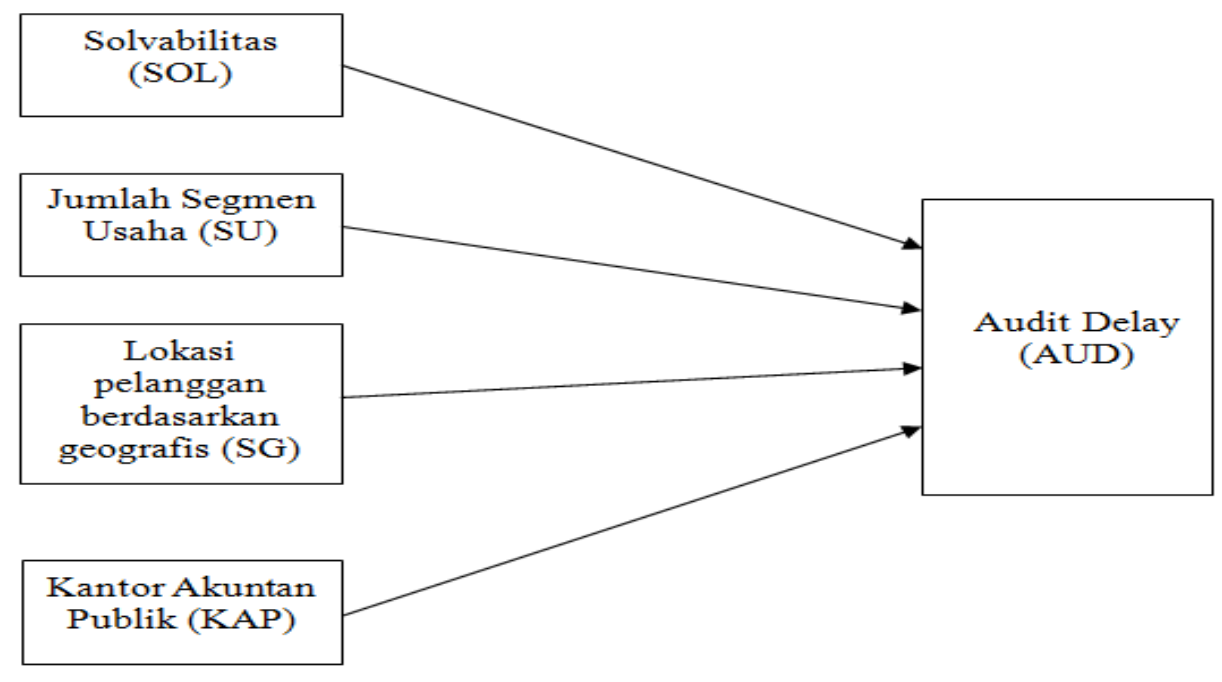

Gambar 1. Kerangka Penelitian

Tujuan penelitian ini adalah untuk mengetahui pengaruh solvabilitas, segmen operasi, dan reputasi KAP terhadap Audit Delay. Adapun manfaat penelitian ini adalah untuk: (a) Bagi Universitas, penelitian ini diharapkan dapat memberikan sumbangan pengetahuan mengenai faktor-faktor yang mempengaruhi audit delay. (b) Bagi peneliti, penelitian ini diharapkan dapat menambah wawasan dan pengetahuan atas penelitian ini mengenai Pengaruh Solvabilitas, Segmen Operasi, dan Reputasi KAP terhadap Audit Delay. (c) Bagi ilmu pengetahuan; hasil penelitian ini menambah body of knowledge dan memperkaya literatur mengenai faktor-faktor yang berpengaruh kepada keinginan berwirausaha.

\section{METODE}

Sampel. Populasi penelitian adalah laporan keuangan tahunan perusahaan yang terdaftar di Bursa Efek Indonesia (BEI) yang diperoleh dari Indonesian Capital Market Directory (ICMD) dan www.idx.co.id. Metode pengambilan sampel dalam penelitian ini adalah menggunakan Purposive sampling yaitu metode pengambilan sampling berdasarkan kriteria-kriteria tertentu (Masri Singarimbun dan Sofian Effendi, 1995). Alasan pemilihan metode ini adalah metode ini mewakili sampel dan dipilih atas dasar kesesuaian karakteristik sampel dengan kriteria pemilihan sampel yang dilakukan. Dalam penelitian ini, kriteria yang ditetapkan adalah: (a) Perusahaan sektor Manufaktur yang terdaftar 
secara terus menerus di BEI selama tahun 2011 - 2013. (b) Perusahaan yang mempublikasikan laporan keuangan tahunan dalam mata uang Rupiah yang berakhir 31 Desember selama tahun 2011 dan tahun 2013. (c) Laporan keuangan yang berisi tanggal laporan auditor independen

Data dan Teknik Pengumpulan Data. Data yang digunakan dalam penelitian ini adalah data sekunder yaitu laporan keuangan perusahaan manufaktur peiode tahun 2011-2013 yang terdaftar di Bursa Efek Indonesia.

Metode dan Analisis Data. Untuk menguji hipotesis tersebut di atas, peneliti menggunakan model regresi sebagai berikut:

$$
\mathrm{AUD}=\alpha+\beta_{1} \mathrm{SOLV}+\beta_{2 \mathrm{a}} \mathrm{SU}+\beta_{2 \mathrm{~b}} \mathrm{SG}+\beta_{3} \mathrm{KAP}+\varepsilon
$$

Yang terdiri dari: AUD : Audit Delay; SOLV : Rasio tingkat solvabilitas; SU : Jumlah segmen usaha; SG : Lokasi pelanggan berdasarkan geografis; KAP : Kantor Akuntan Publik ; $\alpha$ : Konstanta; $\beta_{1}, \beta_{2}, \beta_{3}$ : Koefisien regresi; $\varepsilon \quad$ : Error

Uji Asumsi Klasik. Uji Normalitas. Model regresi yang baik adalah memiliki distribusi data normal atau mendekati normal (Ghozali, 2011). Untuk mengetahui apakah data berdistribusi normal atau tidak pada penelitian ini digunakan uji Kolmogorov-Smirnov. Dalam uji Kolmogorov-Smirnov (uji K-S), hipotesis nol yang diajukan adalah data tidak berdistribusi normal. Sedangkan hipotesis alternatif nya adalah data berdistribusi normal. Dengan demikian jika hasil uji K-S menunjukkan angka yang signifikan, berarti data yang diuji adalah berdistruibusi tidak normal. Sebaliknya, jika hasil uji K-S tidak signifikan, berarti data berdistribusi normal.Solusi yang dapat dilakukan jika data penelitian yang digunakan tidak berdistribusi normal adalah dengan menambah jumlah sampel lebih dari tiga puluh (Gujarati, 2003).

Uji Multikolinearitas. Uji Multikolinieritas adalah adanya suatu hubungan linier yang sempurna antar variabel bebas.Tujuannya adalah untuk menguji apakah model regresi ditemukan adanya korelasi antar variable bebas.Multikolinieritas terjadi jika nilai Variance Inflation Factor (VIF) melebihi 10.Variance Inflation Factor (VIF) merupakan indikator yang menunjukkan bahwa variabel independen lain masih dalam standar error dengan koefisien regresi (Rachmawati, 2008).

Uji Heteroskedastisitas. Uji Heteroskedastisitas bertujuan untuk menguji apakah dalam model regresi terjadi ketidaksamaanvarian dari residual satu pengamatan terhadap yang lain. Uji ini untukmendeteksi probabilitas yang lebih kecil dari tarif signifikansi $\alpha 5 \%$.

Uji Autokorelasi. Uji ini bertujuan untuk mengetahui apakah dalam suatu model regresi linier terdapat korelasi antara pengganggu pada periode $\mathrm{t}$ dengan kesalahan pada periode $\mathrm{t}$ 1.Alat analisis yang digunakan adalah uji Durbin - Watson Statisik

Pengujian Hipotesis. Setelah dilakukan pengukuran variabel dalam penelitian ini, maka dilakukan pengujian hipotesis. Untuk melakukan keputusan menerima atau menolak hipotesis 
yang diajukan, maka perlu dilakukan pengujian secara statistik yaitu uji signifikansi (uji statistik F) yang menunjukkan apakah variabel independen atau bebas yang dimasukkan dalam model mempunyai pengaruh secara bersama-sama terhadap variabel dependen. Koefisien determinasi $\left(\mathrm{R}^{2}\right)$ digunakan dalam penelitian untuk melihat seberapa besar pengaruh dari variabel independen mempengaruhi variabel dependen. Nilainya diperoleh dari koefisien korelasi yang dikuadratkan

\section{HASIL DAN PEMBAHASAN}

\section{Analisis Statistik Deskriptif.}

Tabel 2. Descriptive Statistics

\begin{tabular}{lcrrrr}
\hline & N & Minimum & Maximum & Mean & Std.Deviation \\
\hline ARL & 273 & 33 & 137 & 75,35 & 14,073 \\
DTE & 273 & $-1,0024$ & 17,4522 & 1,263728 & 1,7525629 \\
SU & 273 & 1 & 6 & 2,79 & 1,291 \\
SO & 273 & 0 & 1 &, 77 &, 424 \\
KAP & 273 & 0 & 1 &, 42 &, 495 \\
Valid N (listwise) & 273 & & & & \\
\hline
\end{tabular}

Hasil Pengujian statistik deskriptif (Tabel 1) yang dihasilkan dari 273 sampel perusahaan yang terdaftar di BEI selama periode penelitian menunjukkan bahwa nilai minimum audit delay yang terjadi adalah 33 hari, nilai maksimum adalah 137 hari dan rata rata audit delay yang terjadi pada periode penelitian ini adalah 75,35 hari dengan standar deviasi 14,073. Rata - rata audit delay ini lebih panjang dibandingkan dengan hasil penelitian yang dilakukan oleh Febrianty (2011) yaitu 27,94 hari, Rachmawati (2012) yaitu 71,54 hari, serta Meylisa dan Estralita (2010) yaitu 72,94 hari. Hasil ini menunjukkan bahwa rata-rata perusahaan sudah menyampaikan laporan keuangan secara tepat waktu, atau kurang dari 90 hari.

Untuk variabel Solvabilitas menunjukkan rata rata $126 \%$, sedangkan nilai minimum adalah $-100 \%$ dan nilai maksimum adalah $174,5 \%$. Hasil ini menunjukkan kemampuan perusahaan dalam memenuhi kewajibannya dengan ekuitas yang dimiliki. Variabel Segmen Operasi yang diproksikan dengan sub variabel segmen usaha dan segmen geografis memiliki nilai rata-rata sebesar 3 (mean 2,79 mendekati 3) dan 1 (memiliki geografis multinasional), dengan masing masing standar deviasi 1,291 dan 0,424. Untuk variabel KAP yang diukur dengan dummy 1 dan 0 menunjukkan nilai rata rata 0,41 dengan standar deviasi 0,495 .

Hasil Uji Asumsi Klasik. Normalitas. Dari hasil pengujian (gambar dibawah) didapatkan hasil bahwa nilai Asymp.Sig (2 tailed) adalah 0,004 dan hasilnya lebih kecil dari 0,05 sehingga data terdistribusi secara tidak normal. Namun sampel penelitian yang berjumlah $>100$ (kategori sampel besar), hasil uji ini bisa diabaikan dan distribusi data tetap dianggap normal. Kondisi ini sesuai dengan Central Limit Theory.

Multikolinearitas Model regresi dikatakan tidak terdapat multikolinieritas apabila mempunyai nilai VIF $<10$ dan mempunyai nilai Tolerance $>0,1$. VIF merupakan indikator yang menunjukkan bahwa variabel bebas lain masih dalam standar error dengan 
koefisien regresi. Hasil pengujian multikolinieritas dapat dilihat pada tabel adalah sebagai berikut (Tabel 4).

Tabel 3. Hasil Uji Normalitas

One-Sample Kolmogorov-Smirnov Test

\begin{tabular}{|c|c|c|}
\hline & & Unstandardized Residual \\
\hline $\mathrm{N}$ & & 273 \\
\hline \multirow[t]{5}{*}{ Normal Parameter ${ }^{a, b}$} & Mean & ,0000000 \\
\hline & Std. Deviation & 13,64216504 \\
\hline & Absolute & ,107 \\
\hline & Positive & ,095 \\
\hline & Negative & 107 \\
\hline \multicolumn{2}{|c|}{ Kolmogorov-Smirnov Z } & 1,773 \\
\hline \multicolumn{2}{|l|}{ Asymp. Sig.(2-tailed) } & 004 \\
\hline
\end{tabular}

a. Test distribution is Normal

b. Calculate from data

Tabel 4. Analisis Multikolinearitas

\begin{tabular}{|c|c|c|c|}
\hline \multirow{2}{*}{ Variabel } & \multicolumn{2}{|c|}{ Collinearity Statistic } & \multirow{2}{*}{ Keterangan } \\
\hline & Tolerance & VIF & \\
\hline Solvabilitas / DTE (X1) & 0,944 & 1,059 & Tidak ada Multikolinieritas \\
\hline Segmen Usaha (X2a) & 0,949 & 1,053 & Tidak ada Multikolinieritas \\
\hline Segmen Geografis (X2b) & 0,944 & 1,060 & Tidak ada Multikolinieritas \\
\hline KAP (X3) & 0,998 & 1,002 & Tidak ada Multikolinieritas \\
\hline
\end{tabular}

Heteroskedastisitas. Uji Heteroskedastisitas bertujuan untuk menguji apakah dalam model regresi terjadi ketidaksamaan varian dari residual satu pengamatan terhadap yang lain. Uji ini untuk mendeteksi probabilitas yang lebih kecil dari tarif signifikansi $\alpha 5 \%$ dan dapat dilihat dari hasil scatterplot (Gambar 3) yang menunjukkan data tersebar secara acak di atas maupun di bawah angka 0 pada sumbu Y.

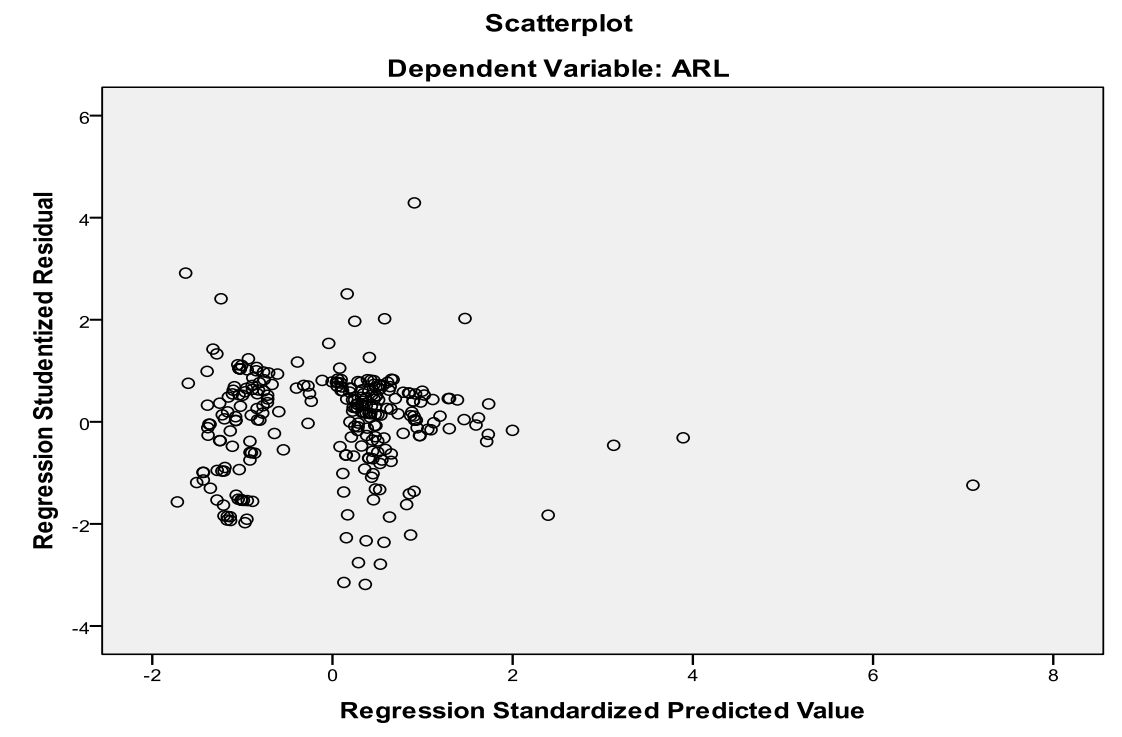

Gambar 1. Hasil Uji Heteroskedastisitas 
Autokorelasi. Uji autokorelasi bertujuan untuk mengetahui apakah dalam suatu model regresi linear terdapat korelasi antara penggangu pada periode $t$ dengan kesalahan pada periode t-1. Alat analisis yang digunakan adalah Durbin Watson. Hasil dari pengujian ini (Tabel 4) adalah 1,805. sehingga disimpulkan tidak adanya autokorelasi.

Tabel 4. Autokorelasi

Model Summary ${ }^{\mathrm{b}}$

\begin{tabular}{|c|c|c|c|c|c|}
\hline Model & $\mathrm{R}$ & R Square & $\begin{array}{l}\text { Adjusted } \mathrm{R} \\
\text { Square }\end{array}$ & $\begin{array}{l}\text { Std. Error of } \\
\text { the Estimate }\end{array}$ & $\begin{array}{l}\text { Durbin- } \\
\text { Watson }\end{array}$ \\
\hline 1 & $246^{\mathrm{a}}$ & 060 & ,046 & 13,744 & 1,805 \\
\hline
\end{tabular}

a. Prediction: (Constant), KAP,SO, SU, DTE

b. Dependent Variabel: ARL

Hasil Uji Signifikansi (Uji t dan Uji F). Untuk mengetahui pengaruh variabel bebas yaitu solvabilitas, segmen operasi, dan reputasi KAP terhadap Audit Delay diperlukan pengujian statistik yang secara terinci dengan menggunakan program PASW Statistic 18 dapat dilihat pada Tabel 5.

Tabel 5. Regresi Linear Berganda (Uji Hipotesis t dan Uji F)

\begin{tabular}{lcccc}
\hline \multicolumn{1}{c}{ Variabel } & $\beta$ & Standar Error & $\mathrm{t}_{\text {hitung }}$ & Sig.t \\
\hline Konstanta (a) & 76,706 & 2,505 & 30,616 & 0,000 \\
Solvabilitas / DTE (X1) & 1,401 & 0,489 & 2,862 & 0,005 \\
Segmen Usaha (X2a) & $-0,614$ & 0,662 & $-0,928$ & 0,354 \\
Segmen Geografis (X2b) & 0,918 & 2,021 & 0,454 & 0,650 \\
KAP (X3) & $-4,976$ & 1,684 & $-2,954$ & 0,03 \\
Koefisien Korelasi ( R) & $=0,24498^{\text {a }}$ & a. Predictors : (Constant) \\
Koefisien Determinasi (R $\left.{ }^{2}\right)$ & $=0,06$ & - Solvabilitas, Segmen Operasi, dan \\
F $_{\text {hitung }}$ & $=4,302$ & \multicolumn{3}{c}{ Reputasi KAP } \\
Sig. F & $=0,002^{\text {a }}$ & b. Dependent Variable : \\
& \multicolumn{5}{c}{ Audit Delay } \\
\hline
\end{tabular}

Berdasarkan dari hasil dari output komputer seperti terlihat pada tabel di atas, maka diperoleh persamaan regresi berganda sebagai berikut:

$$
\text { AUD = 76,706 + 1,401 SOLV - 0,614 SU + 0,918 SG - 4,976 KAP }
$$

Hasil uji t menjelaskan konstanta yang bernilai positif menunjukkan bahwa solvabilitas, segmen usaha, segmen geografis dan Reputasi KAP konstan, maka audit delay yang terjadi adalah 76,706 hari. Koefisien regresi solvabilitas bernilai positif maka setiap terjadi kenaikan tingkat hutang maka audit delay meningkat sebanyak 1,4 hari. Nilai koefisien segmen usaha menunjukkan hasil negatif 0,614 , yang berarti segmen usaha mempunyai pengaruh negatif dan setiap kenaikan akan mengurangi audit delay sebanyak 0,614 hari. Koefisien segmen geografis bernilai positif, maka setiap kenaikan segmen geografis terjadi peningkatan audit delay sebanyak 0,918 hari. Variabel Reputasi KAP menghasilkan nilai negatif sebesar 4,976, yang berarti Perusahaan yang menggunakan jasa audit oleh KAP Big Four mempunyai audit delay yang lebih pendek 4,976 hari dibandingkan yang diaudit oleh KAP Non Big Four. 
Hasil uji F menjelaskan bahwa variabel independen (Solvabilitas, Segmen Operasi, dan Reputasi KAP) mempunyai signifikansi $\mathrm{F}$ hitung sebesar 4,302 dengan tingkat signifikansi yang lebih kecil dari 0,05 (Tabel 5.4). Dengan demikian, dapat dijelaskan bahwa variabel-variabel indpoenden yang diteliti berpengaruh terhadap audit delay.

Koefisien Determinasi $\left(\mathbf{R}^{2}\right)$. Nilai koefisien determinasi yang dihasilkan dari penelitian ini (tabel 5) adalah 6\% yang berarti variabel yang digunakan hanya mampu menjelaskan sebesar $6 \%$ dan sisanya 94\% dijelaskan oleh variabel lain di luar model.

Pembahasan. Berdasarkan hasil uji hipotesis di atas, hasil deskriptif variabel solvabilitas yang diukur dengan perbandingan jumlah hutang terhadap jumlah ekuitas menunjukkan hasil rata-rata sebesar 1,26 yang berarti bahwa dalam memenuhi kewajiban jangka pendek maupun jangka panjang perusahaan menjaminkan sebesar 1,26 ekuitas yang dimiliki oleh perusahaan. Ini juga dapat diartikan bahwa jumlah hutang perusahaan lebih besar dari jumlah ekuitas yang dimiliki, sehingga dapat menimbulkan sinyal bahwa adanya masalah dalam perusahaan dan mengakibatkan perusahaan terlambat dalam menyampaikan laporan keuangan. Hal ini semakin diperkuat dengan nilai signifikansi yang dihasilkan oleh variabel solvabilitas yaitu 0,005. Nilai tersebut lebih kecil dari tarif signifikansi $5 \%$. Sehingga keputusan yang diambil adalah terima H1 dan tolak H0. Hasil ini didukung oleh penelitian yang dilakukan oleh Febrianty (2011), Supriyati dan Rosmawati (2012) yang menunjukkan variabel solvabilitas berpengaruh signifikan terhadap audit delay. Hasil penelitian yang berbeda diperoleh oleh Karim dan Ahmed (2006), Shultoni (2012).

Variabel Segmen operasi yang diproksikan oleh jumlah segmen usaha menunjukkan nilai koefisien regresi negatif signifikan, bertolak belakang dengan hipotesis yang dijabarkan. Hal ini disebabkan oleh sampel perusahaan rata-rata memiliki segmen usaha 2,79 dan banyak diaudit oleh KAP Big Four sehingga tidak membutuhkan waktu yang lama dan memperpendek audit delay yang terjadi sedangkan hasil segmen geografis menunjukkan nilai positif sebesar 0,77, lebih besar dibandingkan tarif signifikansi 5\%, dan disimpulkan bahwa keputusan yang diambil adalah tolak $\mathrm{H} 2 \mathrm{a}$ dan $\mathrm{H} 2 \mathrm{~b}$, terima $\mathrm{H} 0$. Pernyataan ini bertolak belakang dengan hasil penelitian yang dilakukan oleh Wan Hussin dan Bamahros (2012) serta Knechel dan Sharma (2008) yang menemukan adanya pengaruh signifikan. Dari hasil tersebut, dapat disimpulkan bahwa semakin banyak segmen yang dimiliki oleh suatu perusahaan belum tentu mempengaruhi jangka waktu penyampaian laporan keuangan.

Hasil uji hipotesis variable Reputasi Kantor Akuntan Publik menunjukkan pengaruh terhadap audit delay. Hal ini terlihat dari hasil koefisien regresi yang dihasilkan yaitu 0,03 lebih kecil dibandingkan dengan tarif signifikansi $\alpha=0,05$. Hal ini dapat terlihat banyaknya perusahaan yang diaudit oleh Kantor Akuntan Publik Big Four lebih cepat dalam menyampaikan laporan keuangan tahunan. Kesimpulan dari uji hipotesis ini adalah terima H3 dan tolak H0. Pernyataan ini didukung oleh hasil penelitian yang telah dilakukan oleh Rachmawati (2012), dan Shultoni (2012). Sedangkan hasil dari penelitian yang dilakukan oleh Kartika (2009), dan Febrianty (2011), variabel Reputasi KAP menunjukkan hasil yang tidak signifikan.

\section{PENUTUP}


Kesimpulan. Hasil penelitian ini adalah: Pertama. Variabel solvabilitas berpengaruh positif terhadap audit delay. Hal ini menunjukkan bahwa tingkat leverage perusahaan yang rendah cenderung ingin segera mempublikasikan laporan keuangannya, sebab hal tersebut merupakan good news yang akan mempertinggi nilai perusahaan di mata pihak-pihak berkepentingan. Sedangkan tingkat leverage perusahaan yang tinggi memicu terjadinya kemunduran dalam mempublikasi laporan keuangan oleh manajemen perusahaan. Kedua. Segemen Operasi perusahaan yang diproksikan oleh jumlah segmen usaha dan segmen geografi berpengaruh negatif terhadap Audit Delay. Alasan terjadinya pengaruh negatif adalah disebabkan oleh sampel perusahaan rata-rata diaudit oleh KAP Big Four yang memiliki sumber daya yang banyak (tenaga auditornya lebih banyak dibanding KAP Non Big Four), sistem informasi yang canggih, serta memiliki sistem kerja audit yang baik sehingga akan cepat dalam penyelesaian laporan keuangan. Ketiga. Reputasi KAP berpengaruh positif terhadap Audit Delay. Hal ini dikarenakan semakin besar KAP semakin banyak memiliki sumber daya manusia, lebih banyak auditor ahli, dan sistem informasi yang canggih serta memiliki sistem kerja audit yang baik sehingga akan cepat dalam penyelesaian laporan keuangan. Selain itu, reputasi KAP yang baik juga akan lebih tepat waktu dalam penyampaian laporan keuangan untuk menjaga image atau citra KAP dimata publik.

Saran. Berdasarkan kesimpulan dari hasil pengujian statistik di atas, maka saran-saran yang kiranya dapat bermanfaat bagi pihak yang hendak melakukan pengembangan penelitian selanjutnya adalah sebagai berikut. (1) Bagi akademisi. diharapkan dapat melanjutkan penelitian ini dengan menambah variabel lain yang dapat mempengaruhi Audit Delay seperti keberadaan internal expert/ internal auditor dan sebagainya. (2) Bagi universitas khususnya pengajar, dapat menciptakan satu sarana pembelajaran yang memberikan perilaku positif bagi mahasiswa akuntansi dalam proses belajar mengajar, diantaranya adalah melalui penggunaan media maupun perpustakaan sebagai penunjang perilaku dan kebiasaan belajar dari mahasiswa akuntansi FE UNTAR.

Implikasi. Penelitian ini diharapkan dapat memberikan masukan bagi pengajar FE UNTAR yang juga bekerja sebagai Auditor, membantu mereka dalam mengidentifikasi faktor-faktor apa saja yang mempengaruhi Audit Delay. Penelitian ini juga diharapkan dapat membantu pengajar FE UNTAR (berprofesi sebagai auditor) dalam upaya meningkatkan efisiensi dan efektivitas proses audit dengan mengendalikan faktor-faktor dominan yang menyebabkan terjadinya Audit Delay.

\section{DAFTAR RUJUKAN}

Ankarath.N, Mehta. K.J., Ghosh. Dr.T.P, dan Alkafaji.Dr.Y.A. (2010) Memahami IFRS Standar Pelaporan Keuangan Internasional. Jakarta: PT. Indeks

Arens, Alvin A, Randal J. Elder dan Mark S. Beasley., (2008) Auditing dan JasaAssurance: Pendekatan Terintegrasi, Jilid 1, ed. 12, Alih Bahasa: Herman Wibowo. Jakarta: Erlangga.

Bestari. M dan Siregar,S.V. (2012) Determinan Motif Pengungkapan Variasi Pertumbuhan Laba Antar Segmen Perusahaan Manufaktur Yang Terdaftar di Indonesia. SNA XV Banjarmasin 20-23 September. 
David et.al,. (2013) The Relationship between segment - level manipulations and audit Fees. The Journal of Applied Business Research July/August 2013 Vol. 29 No. 4.

Ettredge, Michael, Chan Li, and Lili Sun. (2006) The Impact of Internal Control Quality on Audit Delay in the SOX Era.

Febrianty. (2011) "Faktor - Faktor Yang Berpengaruh Terhadap Audit Delay Perusahaan Sektor Perdagangan Yang Terdaftar di BEI 2007-2009”. Jurnal Ekonomi dan Informasi Akuntansi (JENIUS) vol. 1 No. 3 September.

Fitriany dan Aulia.(2009) PSAK No.5: Faktor Yang Mempengaruhi Pengungkapan Dan Dampaknya Terhadap Forward Earnings Response Coefficient. SNA XII Palembang 4-6 November.

Ghozali, Imam.(2011) Aplikasi Analisis Multivariate dengan Program IBMSPSS19,Badan Penerbit Universitas Diponegoro, Semarang.

Ikatan Akuntan Indonesia.(2012) Standar Akuntansi Keuangan Per1 Juni 2012. Jakarta: Salemba Empat.

Indonesian Capital Market Directory (2011) Ttwenty-Second Edition. ECFIN.

Indonesian Capital Market Directory volume 1(2012). Twenty-third Edition. ECFIN.

Karim et.al. (2006) The Effect of regulation on timeliness of Corporate Financial Reporting: Evidence from Bangladesh. JOAAG Volume 1 No. 1.

Kartika, A.(2009) Faktor-faktor yang mempengaruhi Audit Delay di Indonesia (Studi Empiris pada Perusahaan LQ45 yang terdaftar di Bursa Efek Jakarta. Jurnal Bisnis \& Ekonomi (JBE), 16 (1): 1-17.

Kieso, D.E, Weygant, J.W. \& Warfield, T.D. (2011) Intermediate Accounting IFRS Edition Volume 1 and 2. John Wiley\&Sons.

Knechel and Sharma. (2008) Auditor Provided Non-Audit services and Audit Effectiveness and Efficiency: Evidence from pre- and post- Sox Audit Report Lags.

Lee and Jahng. (2008). Determinants of Audit Report Lag: Evidence from Korea - An Examination of Auditor Related Factors. The Journal of Applied Business Research - Second Quarter 2008.Vol.24 No.2.

Lambert,Tamara.A,Joseph F. Brazel and Keith L. Jones. (2007) Unintended Consequences of Accelerated Fillings: Do Changes in Audit Delay to Changes in Earnings Quality.

Lianto, N dan Kusuma.B.H. (2010) "Faktor - Faktor yang berpengaruh terhadap Audit Report Lag”. Jurnal Bisnis \& Akuntansi, 12 (1): 97-106.

Meylisa dan Estralita. (2010) "Faktor Faktor yang mempengaruhi Audit Report Lag Pada Perusahaan yang terdaftar di BEI". Jurnal Bisnis \& Akuntansi, 12 (3): 175-186.

Prince.et.al. (2012) "Determinants of Audit Delay in Nigerian Companies: Empirical Evidence Research". Journal of Finance and Accounting, ISSN 2222-1697 (Paper).ISSN 2222-2847 (Online), 3 (6).

Putra, P.D dan Roza.T .(2013) Analisis faktor yang mempengaruhi ketepatan waktu penyampaian laporan keuangan pada perusahaan yang listing di BEI periode 20082012. Jurnal BINA Akuntansi IBBI, 18 (1), ISSN 1858-3202

Rachmawati, S. (2008) "Pengaruh Faktor Internal dan Eksternal Perusahaan terhadap Audit delay dan Timeliness". Jurnal Akuntansi dan Keuangan, 10 (1) Mei: 1-10

Rosmawati dan Supriyati. (2012) Faktor-faktor yang mempengaruhi Audit Report Lag pada perusahaan manufaktur di Indonesia dan Malaysia. The Indonesian Accounting Review, 2 (2): 185-202. 
Shultoni,M. (2012) "Determinan Audit Delay dan Pengaruhnya terhadap Reaksi Investor (Studi Empiris pada Perusahaan yang listing di BEI tahun 2007-2008)". Jurnal Akuntansi dan Ekonomi Bisnis, 1 (1)

Shukeri, S.N and Islam, M.A. (2012) "The Determinants of audit timeliness: Evidence from Malaysia". Journal of Applied Science Research, 8(7): 3314-3322.ISSN 1819$544 \mathrm{X}$

Singarimbun, Masri dan Sofian Effendi. (1995) Metode Penelitian Survai. Jakarta: LP3ES Standar Profesional Akuntan Publik / Institut Akuntan Publik Indonesia. (2011). Jakarta: Salemba Empat

Subramanyam, Wild. (2009) Financial Statement Analysis. New York: McGraw Hill

Sugiyono. (2009) Metode Penelitian Kuantitatif, Kualitatif dan R\&D. Bandung: CV Alfabeta.

Wan Noordin, W.H., and Bamahros H.M. (2012) Do Investment in and Sourcing arrangement of the Internal Audit Function Affect Audit delay? 